\title{
Home Rule, 1870-1914: an Introduction
}

La Question du Home Rule (1870-1914) : introduction

Anne-Catherine de Bouvier and Pauline Collombier-Lakeman

\section{(2) OpenEdition}

Journals

Electronic version

URL: http://journals.openedition.org/rfcb/3676

DOI: $10.4000 /$ rfcb.3676

ISSN: 2429-4373

\section{Publisher}

CRECIB - Centre de recherche et d'études en civilisation britannique

\section{Electronic reference}

Anne-Catherine de Bouvier and Pauline Collombier-Lakeman, «Home Rule, 1870-1914: an Introduction », Revue Française de Civilisation Britannique [Online], XXIV-2 | 2019, Online since 19 June 2019, connection on 23 September 2020. URL : http://journals.openedition.org/rfcb/3676 ; DOI https://doi.org/10.4000/rfcb.3676

This text was automatically generated on 23 September 2020 .

\section{c) $(9)$}

Revue française de civilisation britannique est mis à disposition selon les termes de la licence Creative Commons Attribution - Pas d'Utilisation Commerciale - Pas de Modification 4.0 International. 


\title{
Home Rule, 1870-1914: an Introduction
}

\author{
La Question du Home Rule (1870-1914) : introduction
}

Anne-Catherine de Bouvier and Pauline Collombier-Lakeman

1 Recent events have been raising the question of the future of the British Union. The results of the Brexit referendum in Scotland, which showed that a majority of the Scots backed the remain option, contrary to the Welsh and the English, have given fresh impetus to the idea of organising a second referendum on Scottish independence following the failure of the first one in September 2014. In Northern Ireland, where a majority of voters also supported the United Kingdom's remaining in the UE, the absence of a deal accepted by all while the exit date of 29 March is closer and closer has been a source of growing concern and tensions as the question of the Northern Irish border is still unresolved. These intense political debates have coincided with new historiographical developments. Since 2012, the Republic of Ireland has been engaged in a Decade of Commemorations, celebrating and re-examining the events between 1912 and 1922, which led to the creation of the Irish Free State and, more than two decades later, to the Irish Republic itself. The community of professional historians and the whole country itself are faced with delicate questions: how to commemorate partition? Or how to commemorate the civil war that followed the signature of the Anglo-Irish treaty of December 1921?

2 In such circumstances, it seems particularly relevant for students and scholars in France to explore the Home Rule issue as the period between 1870 and 1914 witnessed the laying of the foundations of many of the recent developments and issues experienced by the United Kingdom today.

3 The issue of Home Rule encompasses both a historical dimension and a geographical dimension. The choice of timeframe - 1870-1914 - requires to consider the subject in terms of departure and continuity. And while D. G. Boyce provokingly asserts that " British federalism was an Irish invention", ${ }^{1}$ the question of Home Rule was certainly not a mere Irish concern. The case of Ireland may have dominated the discussions and it was in Ireland - not in Scotland, Wales or England - that a Home Rule party saw the light. 
Only the Irish Home Rule Bill passed the Lords, and was due to be implemented, though with the momentous proviso that an arrangement should be found to accommodate Ulster Unionists. Irish Home Rule came first, chronologically and in the parliamentary agenda, and alternative proposals such as imperial federation or Home Rule All Round were often put forward, either to bolster Irish Home Rule, or conversely to defuse it. It seems that it was the impetus for Irish Home Rule which gave rise to other claims for self-government and federalism. But while the issue of Home Rule was raised from Ireland, it was not exclusively for it. The fact that the debates on Irish Home Rule had a significant influence on British politics and resonated across the wide British Empire also highlights the necessity to take into account a variety of scales. Home Rule can be studied as an Irish or Scottish or Welsh issue; it can also be examined as an Anglo-Irish and British question; and it was also an imperial matter. In other words, questions to bear in mind include: what was the area considered? What was the perimeter in which Home Rule was articulated, demanded, to be granted, or rejected? What did it mean, and where? And, crucially, could London gain something by this form of devolution of powers?

4 As an Irish question, Home Rule aimed at pacifying Ireland and attaching her more firmly to the Union by securing popular consent to government. Yet it was also suspected to be a stepping stone to independence, especially when Irish figureheads stated that "no man ha[d] the right to fix the boundaries to the march of a nation." Home Rule for Ireland also meant the restoration of an Irish Parliament charged with legislating on Irish affairs while the Westminster Parliament remained responsible for a number of reserved matters such as the Empire, foreign affairs, war and peace, currency, etc. The coexistence of a local and central Parliament raised the problem of Irish representation at Westminster: Gladstone opted to keep the Irish out of Parliament in 1886, provoking the protest of radicals such as Joseph Chamberlain and George Otto Trevelyan, for whom this equated to "taxation without representation." The following 1893 and 1912 Bills included an Irish representation at Westminster, which sparked other concerns: the Irish would be in position to vote on Scottish, Welsh or English Bills while the Scottish, Welsh and English would not longer be able to have a say in Irish affairs. The solution to such a conundrum was "Home Rule All Round". At its largest interpretation, it entailed four provincial parliaments with separate executives, with an overall Parliament in London, elected on a population basis, to deal with general United Kingdom and imperial affairs. While "Home Rule All Round" and simple "Home Rule" both promoted the principle of self-government, they were not identical projects and reflected aspirations that were not strictly similar. The Home Rule All Round schemes promoted by the Scots and Welsh did not stem from a desire to see Scotland and Wales recognised and treated as separate and distinct nations. The aim was rather to remove pressure on the parliamentary agenda, ensure that local issues were given quick and relevant answers and even dilute the Irish question and deprive it of its potential challenge to a certain form of government. At a wider level, some envisaged and promoted the formation of an Imperial federation - a system in which Westminster was to act as the central body representing and legislating all the British colonies while they were to be self-governing. Again, Home Rule and imperial federation were not regarded as compatible by all since the aim of imperial federation was to preserve the unity and strength of the British Empire without compromising the legislative autonomy gained by some of its parts. For some of the federal imperialists, Home Rule was therefore to be rejected as it represented a threat to the Empire. But for 
the federal imperialists not opposed to Home Rule for Ireland or its sister provinces within the Union, Home Rule could represent a first step towards imperial federation and what was advocated was a way to accommodate the multiple identities present in the Union and the Empire and, at the same time, give more substance and permanence to the empire.

One of the difficulties of the subject, which also makes it interesting, is that the issue was largely left unresolved. Completion of the Scottish Home Rule Bill, and more crucially, implementation of the Irish Home Rule Bill were postponed owing to the outbreak of World War I. After the war, the issue had lost its acumen, and its impetus: in Ireland, the demand that emerged was of one of full autonomy - which London was reluctant to grant, to say the least. In Scotland and Wales support for Home Rule had dwindled and faded away. By 1918 (perhaps even as early as August 1914), Home Rule was a thing of the past.

Home Rule made little practical headway over the 45-year period considered in spite of the huge interest it generated. First, there was the very novelty of the schemes. Second, there was their variety. Last, the very idea of a devolution of powers through subordinate legislatures was a departure from the workings of the Constitution. Whatever the specific provisions, the relations between this new or these new assemblies on the one hand, and Westminster and Whitehall, would have to be set down. This meant the end of the elusive quality of the British constitution in its unwritten form. In addition, there would be no tradition, no centuries of practice to draw rules from. In spite of the various precedents that could be drawn upon (the example of Canada, for instance), Home Rule within the framework of the United Kingdom was an unchartered course - in other words, it was just as tempting to explore its possibilities to provide new responses in a changing international and domestic environment, as it could seem dangerous to pursue it, precisely because of this flux in domestic arrangements and international affairs. All of the uncertainties conveyed by the various Home Rule schemes were instrumental in fuelling the Unionist opposition.

Because Home Rule was never implemented within the United Kingdom before 1914, we are left to conjecture upon a pattern that never came into being. There is no knowing how an Irish parliament would have worked with a British, London-based Parliament; how devolved Irish institutions would have dealt with a possible or likely Northern Irish entity; no knowing whether Irish politics would have drifted back along a Liberal / Conservative / Labour division, or would have evolved into a specific pattern. Whether effective alliances might have been formed with local parties in other parts of the United Kingdom; how the people would have appropriated these new institutions, and whether they would have credited them with the legitimacy that centralized institutions sometimes failed to command. ${ }^{2}$ Home Rule was therefore never put to the test, and as a result, there was no ultimate clarification of its definition. The multiple understandings of the phrase itself, explicit and implicit, are one of the challenges we are presented with. What did Home Rule mean, where, and for whom? The question of definition pervaded the debates, as is clearly conveyed by the titles chosen for some of the pamphlets written by our Irish Home Rulers or for some of their spoken conferences: Irish Federalism: Its Meaning, Its Hopes by Isaac Butt (1870), "Home Rule - Its real meaning" (John Redmond, Melbourne, 1883) or What Ireland Wants by John Redmond (1910). In a speech delivered by Redmond during the debates on the address to the Queen's speech on 13 March 1894, the Parnellite leader even showed the role 
that the problem of the definition of Home Rule played in the power game between the Irish nationalists and the British Liberals:

There is another matter about which we have heard absolutely nothing in any of the Ministerial statements, and that is whether Lord Rosebery, in speaking of Home Rule, means the same thing as the Chief Secretary and the same thing as we mean. Does he mean the Home Rule Bill, which was passed through this House last year? (...)

By "Home Rule" we Irishmen mean something more than a purely local selfgovernment for purely local affairs. We mean by "Home Rule" a government which would be consistent with the supremacy of this Parliament, and with our position in the Empire, a National Government with something of the pride and the honour attaching to a National Government and a National Parliament. ${ }^{3}$

Plenty of texts and documents were produced during our period to actually explain more in detail and advocate what Home Rulers wanted and to present alternatives to or criticisms of Home Rule. In the case of Ireland especially, propaganda, in all its shapes and forms, triggered numerous Unionist responses. ${ }^{4}$ However there was no test of the two opposite sets of arguments. Thus, Irish Home Rule could still have been either a way of smoothing the relation between Ireland and England, or a separatist wolf in sheep's clothing. Yet, paradoxically, Home Rule is also something that happened - at least in debates, and in the political paradigm of the day. For Ulster Unionists, Home Rule must have been something very real from 1886 onwards 5 . Ironically, it became real in 1922, when, in addition to the creation of the Irish Free State, Home Rule was put into place in the six counties of Northern Ireland with the establishment of a Parliament in Stormont.

What history of Home Rule could and can be charted is largely the history of the Home Rule Bills. Not only were there three Government bills introduced in favour of Irish self-government in 1886, 1893 and 1912. These were preceded by three attempts by Isaac Butt to obtain the establishment of a parliamentary committee charged with examining the question of the Anglo-Irish Union and the possibility of legislative autonomy for Ireland - in March 1874, June-July 1874, and on 30 June 1876. To that needs to be added the many private member's bills introduced by Scottish MPs in favour of Scottish Home Rule or federal Home Rule: no fewer than 13 motions were discussed between 1889 and 1914, notably between 1889 and 1895 and then between 1906 and 1914. While Welsh MPs were primarily concerned by other Welsh issues than self-government, they did second some of the motions presented by their Scottish colleagues (in 1891 or 1895 for instance) and one of them, E. T. John, did introduce a short-lived Welsh Home Rule Bill on 11 March 1914. By the years 1912-1914 a striking number of Home Rule Bills had followed their parliamentary course to second reading in the House of Commons, though few of them actually passed committee stage and onto third reading.

The frequency of the Home Rule parliamentary debates highlights that Home Rule could not exist outside of Parliament. It had an unquestionable institutional dimension - and we should always remember that institutions are not merely theoretical constructs. They are, properly speaking, historical objects, whose rules and composition were profoundly transformed throughout the nineteenth and early twentieth centuries. The Parliament that was called upon to frame and/or pronounce upon Home Rule Bills in the years preceding 1914 was no longer the same institution as in 1874, when Isaac Butt had first raised the issue in the House of Commons. Its electoral basis had changed. MPs were returned by more and more men, lower and 
lower down the social scale. The number of adult males enjoying the franchise increased as follows throughout the nineteenth century:

Figure 1 - Proportion of adult male voters in the four provinces of the United Kingdom ${ }^{6}$

\begin{tabular}{|l|l|l|l|}
\hline Year & England \& Wales & Scotland & Ireland \\
\hline 1833 & 1 out of 5 & 1 out of 8 & 1 out of 20 \\
\hline 1869 & 1 out of 3 & 1 out of 3 & 1 out of 6 \\
\hline 1885 & 2 out of 3 & 3 out of 5 & 1 out of 2 \\
\hline
\end{tabular}

11 This progressive and yet incomplete democratisation of Britain inevitably impacted the House of Commons, whose sociological composition also changed, though to a lesser extent. Ultimately, the traditional balance of power between the two Houses of Parliament was modified, leading to a major institutional crisis. As the House of Lords persisted in rejecting touchstone aspects of policy on the part of the Liberal government - not least the so-called People's Budget defended by Lloyd George in 1909 - Asquith had to call two general elections in 1910, a situation which not even Theresa May has faced so far. The resolution of the tensions was operated through a reform of the House of Lords. The Upper House was left with two-year suspensive powers - the balance of power had clearly shifted towards the lower House.

According to Walter Bagehot, the Lords as well as the monarchy belong to the "dignified" and invisible part of the Constitution, while the House of Commons and the executive belong to what he calls the "efficient" part. The Home Rule debates from the 1880 s onwards, later combined with the crisis generated by the growing tensions between the two Houses of Parliament, made this "invisible" part suddenly more visible. Queen Victoria's general hostility to Gladstone is well documented, leading a recent account on the subject to state that "[ $t$ ] he tension that existed between these two great icons of nineteenth-century Britain has achieved cliché status with time." While Conservative Premier B. Disraeli had Victoria proclaimed empress of India in 1877, Gladstone had published scathing comments on the weight of imperial concerns, which according to him had caused the British Government to turn a blind eye and thus condone the so-called "Bulgarian atrocities." ${ }^{8}$ Gladstone's Irish policy met with royal disapproval as early as his first ministry. If the Queen had stomached disestablishment in 1869, she opposed the setting up of a Royal Residence in Dublin, and the establishment of the vice-royalty as a ceremonial position to the Prince of Wales, which Gladstone had intended as part of his policy of pacification. ${ }^{9}$ While Victoria seems to have viewed favourably the accession of some colonies to autonomous government or self-rule, she was firm in her opposition to the granting of any similar rights to Ireland. ${ }^{10}$ In July 1886, Gladstone resigned over the failure of his first Irish Home Rule Bill and the Liberal defeat at the general elections. During the debates on the Bill, Victoria made clear her opposition to her Prime Minister's measure, stating in her letter dated 6 May that "her silence on the momentous Irish measures which he [thought] it his duty to bring forward - [did] not imply her approval of or acquiescence in them." Upon the announcement of Gladstone's resignation and the appointment of Lord Salisbury as his replacement, the Queen appealed to the Liberal leader's "sense of patriotism" to 
convince him to "abstain from encouraging agitation" as "the kindest \& wisest thing he [could] do for Ireland." 11 This opposition certainly signalled that she considered the Irish as second-class, unreliable subjects. Hard as it is to assess the political impact of the sovereign's opinions, it can nonetheless be inferred that her position legitimized die-hard opposition to Home Rule, while bringing fuel to the fire of those who argued that Ireland could never be treated as an equal partner in the Union. To take up again Bagehot's categories, the dignified part of the constitution stood firm against Home Rule.

13 However, the reign of George V, who acceded to the throne in May 1910, at the height of the crisis between the Lords and the Commons, witnessed a change in the attitude of the British monarchy towards Ireland and the Irish issue. His father, Edward VII, had told Asquith privately that in the absence of consent of the Lords to a reform of their House, he was willing to create enough new peers to outvote them - but only after another election was held. George V did not alter this line. A new election was held, a Reform Bill was brought in, to which the Lords eventually gave reluctant agreement some of the argument rested on the constitutional future of Ireland. The 1911 Parliament Act brought an end to the conflict between the two houses of Parliament, and acknowledged that the ultimate source of authority lay in the Commons, as the House springing from democratic power.

While this opened the way for the return of Home Rule on the parliamentary agenda, it also contributed to the radicalisation of unionism, and particularly of Ulster Unionism, as the bulwark of the Union was no more. Such opposition meant business, and it was clear that the calls to armed resistance to Home Rule were no idle talk. How then, to avert the prospect of immediate civil war upon the passing of the Irish Home Rule Bill? Partition had been aired in Parliament, and discussed behind the scene. How to make it acceptable to Home Rulers, and what to include in 'statutory Ulster' that would meet with non opposition on the part of Unionists? Such was the object of the Buckingham Conference, an all-party conference convened by George $\mathrm{V}$ and held at Buckingham palace between $21^{\text {st }}-24^{\text {th }}$ July 1914 , in order to determine upon the area to be partitioned. Let there be no suspense: all options were put on the table: county divisions, constituency divisions, but no agreement was reached. In History Ireland, Kieran J. Rankin offers a severe assessment of the conference as "an altruistic but futile attempt to broker a partition arrangement; there was little incentive to make concessions despite there being no shortage of ideas on how 'statutory Ulster' could be composed." ${ }^{12}$ Still, this was some kind of an attempt, and if George $\mathrm{V}$ cannot be credited with success, he cannot be blamed for indifference either as some of his statements at the time of the Buckingham Palace Conference organised in July 1914 show:

We have in the past endeavoured to act as a civilising example to the world, and to me it is unthinkable, and it must be to you, that we should be brought to the brink of fratricidal strife upon issues apparently so capable of adjustment as those you are now asked to consider, if handled in a spirit of generous compromise.

(...) My apprehension in contemplating such a dire calamity is intensified by my feelings of attachment to Ireland and of sympathy to her people, who have always welcomed me with warmhearted affection. ${ }^{13}$

There was cause indeed for such apprehension: since 1912, crisis in Ulster had loomed larger and larger. During the debates on the third Home Rule Bill, Edward Carson had featured as a prominent orator. In January 1913, he stated the case for partition, insisting upon an amendment to the bill stating "except in the province of Ulster". 
Challenged by an MP to state what he meant, he answered "when I speak of Ulster I mean Unionist Ulster. ${ }^{14 "}$ "This, clearly, could not mean the whole geographical and historical province, but how to map unionism to practical effect? Should counties be considered, or constituencies? Could maps of religious affiliation provide a sure guide as to the location of Unionism? Without going into the arcane details of defining "statutory Ulster ", as distinct at least from historical Ulster, we shall merely observe that the Ulster crisis interrogates again the connection existing between place and politics, or place and political concept, which is one of the difficulties of the subject of Home Rule.

The early $21^{\text {st }}$ century student of Home Rule may be tempted to reduce the issue to one of national, or regional, identity, conceived as unified, and exclusive. This definition is to be rejected, as it would definitely obscure several major points. First, identity is not marmoreal. Shortly before his death in 1862, one leading member of the Beresford family had commented "When I was a boy, the 'Irish people' meant the Protestant, now it means the Roman Catholics." ${ }^{15}$ Rigid definitions of identity rest upon the rationale for later political divisions and borders, and tend to obscure complexity.

French students in particular are apt to mishandle the Catholic-Protestant issue. At that stage, the political significance of religion must be borne in mind. Any one familiar with the Catholic tradition will feel fairly at home in an Anglican service, and quite perplexed at a Quaker or Presbyterian worship. Policy was at stake, rather than doctrine. In the case of Ireland, Scotland, and Wales, religious specificity unquestionably played a part in the construction of identity. But making an absolute link between identity and Home Rule would somehow establish a hierarchy: the Irish identity (defined as native, Catholic and nationalist, which is a questionable definition) would thus appear stronger than the Scottish, or Welsh identities. This makes no sense; and if we take the prevalence of the regional language as an indicator, Welsh seems to have fared better than the Irish language. In the case of Ireland, support of the Catholic hierarchy for Home Rule should not be construed as identity nationalism. It was also the result of political calculation: the prospect of Home Rule offered the best guarantees of safeguarding/strengthening the Church's hold on education at all levels, and of securing its control over a nascent system of social protection. Plus, making Catholicism an element of definition Irishness excludes Protestants - not only individual Protestants too hastily written off as exceptions (Butt, Parnell), but Ulster Protestants. Did Unionism mean the same in Dublin, Belfast, Derry or London?

One should beware of implicit assumptions of supposedly pure, stable and homogeneous identities - and especially of exclusive ones. Considering the making of Britain in the $18^{\text {th }}$ century, Linda Colley argues that Britishness was "superimposed on much older allegiances", i.e. Welshness, Englishness or Scottishness. ${ }^{16}$ The experience of Ireland, Wales, or Scotland, was not necessarily exclusive of interaction with the other nations of the British Isles. Nor did it imply that empire was necessarily synonymous with oppression. For the last two to three decades, historians have started to reexamine the history of the British empire and have notably highlighted the existence of " imperial circuits and networks" thanks to which ideas, knowledge, commodities and men circulated. The empire has been presented as a space including "contact zones", i. e. " space[s] in which peoples, geographically and historically separated [came] into contact with each other and establish [ed] ongoing relations, usually involving conditions of coercion, radical inequality, and intractable conflict." ${ }^{17}$ Interpretations of the history of Ireland, both as a member of the British empire and as a nation aspiring to some degree of political 
independence, have been affected by these new perspectives on imperial history and an increasing number of recent publications have, as a result, shed fresh light on the deep links and multiple interactions between Ireland and the rest of the empire. Research has notably focused on the Irish in the British empire - as clerks, doctors or nurses, artists, members of the judiciary, and even soldiers and officers ${ }^{18}$. The fact that Ireland had been conquered and planted and had also taken part in the British imperial project meant that, even after the passing of the Acts of Union of 1800, which theoretically transformed Ireland into a British province, Ireland had a multifaceted and hybrid political identity:

For the next 120 years Ireland was, legislatively, to be part of a unitary United Kingdom: on a constitutional level at least the never clearly defined "colonial" status of Ireland had ended. (...) Yet on other levels and by other definitions the country's position as a subordinated part of the British imperial system was intensified, not ended, by Union. ${ }^{19}$

Recently in The Irish Times, an article marking the centenary of the Amristar massacre was published and it underlines how complex and ambivalent Ireland's position within the Empire was:
In March and April 1919, Indians rallied across Punjab to protest the Rowlatt Acts; they shut down normal commerce in many cities, demonstrating - through empty streets and shuttered shops - the dissatisfaction of the people at the British betrayal. This was a form of Gandhian non-violent non-cooperation; no violence or disorder was reported. But the British government arrested nationalist leaders in the city of Amritsar and opened fire on protestors, killing 10. In the riot that ensued, five Englishmen were killed and a woman missionary assaulted. (However, she was rescued, and carried to safety, by Indians.)
The British promptly sent troops to Amritsar to restore order, under brigadier general Reginald Dyer. Dyer, who was educated at Midleton College, Cork, reported to and enjoyed the unstinting support of the Tipperary-born lieutenant-governor of Punjab, Sir Michael o'Dwyer.
It is a sobering reminder that the Irish were not merely victims of British imperialism but complicit in it in many parts of the world. ${ }^{20}$

20 It is of very bitter irony that the officers in charge should have been cleared by the House of Lords, for acts which would have matched the behaviour of the Black and Tans in Ireland more or less at the same time, and praised by Kipling. Of course, not all Irishmen, Scots or Welshmen involved in the British empire behaved in so brutal a manner; yet, they participated in its running, hence, in its hegemony.

This invites us to replace the debate on Home Rule within the imperial framework. Over the period, the empire faced a challenge. Part of it lay in its growth: by 1914, the population of the empire was over 400 million people, a little below one fourth of the total population of the globe. Part of it lay in the fierce competition for overseas possessions with other powers - France, Germany, Russia among the fiercest competitors. The years 1866-1871 saw the setting up of the Second Reich, a new German empire where the Prussian element held sway, under the political leadership of Otto Von Bismarck, the arch unifier of the country. At that time, Germany was also proving an increasingly dangerous competitor, economically speaking. How, then, to secure the endurance and growth of the empire? The Home Rule debates must be viewed as part of the imperial question. Was Home Rule likely to strengthen the bonds between the mother country and the empire? Incidentally, what was the mother country - was it England, or Britain, or the United Kingdom? As we saw, one should be wary of rash answers. If so, was it the destiny of all colonies, or at least all white 
colonies that were not physically attached to Great-Britain to become self-governing dominions? And to what category did Ireland belong? Once again, one should be wary of rash answers. On the contrary, was the demand for Home Rule, and in particular for Irish Home Rule, a fundamentally separatist demand, the expression of a centrifugal force which, unchecked, would inevitably lead to the break-up of the empire?

The imperial issue dominated the period. In 1870, Isaac Butt had clearly pointed to an increasingly unstable and politically dangerous international situation in his Irish Federalism. In 24 June 1872, Conservative leader B. Disraeli pronounced his famous Crystal Palace speech, which clearly set down what was to be the Conservative doctrine over empire. The speech opened on a statement defining the priorities of the Tory party: "first (...) to maintain the institutions of the country, (...) second, in my opinion, to uphold the empire of England." These priorities were set to counteract the effects of Liberalism, which was regarded by the Conservative leader as an ideology intent on the " disintegration of the empire." For Disraeli, preventing such disintegration required other measures aimed at strengthening the bonds between the self-governing colonies and the mother country:

Not that I for one object to self-government. I cannot conceive how our distant colonies can have their affairs administered except by self-government. But selfgovernment, in my opinion, when it was conceded, ought to have been conceded as a part of a great policy of imperial consolidation. It ought to have been accompanied by an imperial tariff, by securities for the people of England for the enjoyment of unappropriated lands which belonged to the sovereign as their trustee, and by a military code which should have precisely defined the means and the responsibilities by which the colonies should be defended, and by which, if necessary, this country should call for aid from the colonies themselves. It ought, further, to have been accompanied by the institution of some representative council in the metropolis, which would have brought the colonies into constant and continuous relations with the home government.

Noting the lasting "sympathy of the colonies with the mother country", the Conservative leader concluded nonetheless that England was faced with a choice that would be crucial for the future and survival of the British Empire:

(...) the time is at hand, that, at least, it cannot be far distant, when England will have to decide between national and cosmopolitan principles. The issue is not a mean one. It is whether you will be content to be a comfortable England, modelled and moulded upon continental principles and meeting in due course an inevitable fate, or whether you will be a great country, - an imperial country - a country where your sons, when they rise, rise to paramount positions, and obtain not merely the esteem of their countrymen, but command the respect of the world...21

This speech contains what was to be the Conservative doctrine over empire from then on, often referred to as "empire for the empire's sake" - as indeed it articulates the centrality of empire to Conservatism. It also sets down the Conservative interpretation of self-government: something which ought to be granted to distant colonies. Interestingly, it voices the need for a central, London-based organ of collective deliberation. In time, this became the Conference of the Commonwealth; but during the period under consideration, this would have been quite consistent with the type of central parliament envisaged by the advocates of imperial federation. The Crystal Palace speech further suggests that the empire might provide a possibility of upwards mobility for the people of the British Isles, as it did. However, it contains a problematic reference to territory: the distant colonies are mentioned, so is the mother country, "England", leaving Wales, Scotland, and emphatically Ireland in a sort of in-between 
zone, the definition of which was still undecided when Home Rule was eventually adopted - neither a dominion, nor an ordinary member of the Union. This was pointed by Arthur Balfour in the speech he delivered upon the third reading of the Government of Ireland Bill, on 15 January, 1913:

Broadly speaking, you have done everything you can to take away from the Irish Government that which not only every nation, but every self-governing Dominion of the Crown, possesses in the fullest and amplest measure. They cannot coin; I do not think that is very important except as a symbol or mark of nationality. They cannot look after their self-defence; they cannot raise a man to defend their shores. I do not say that is wrong. What I am pointing out is that you are saying one thing to these gentlemen and another thing to other gentlemen. I do not say it is wrong, if this is a mere measure of local self-government, but I say it is absolutely and ludicrously wrong if this Bill is to give back what the hon. Gentleman the Leader of the Irish party calls the restoration of the national rights of the country. ${ }^{22}$

Home Rule all round would have clarified the matter, at least theoretically.

In the light of all this, the party polarisation of the issue of Home Rule as it developed from 1885 onwards, with Gladstone's so-called conversion to Home Rule for Ireland, has a strong element of continuity to it. The years $1884-85-86$ can certainly be described as a turning point with the enfranchisement of a large proportion of the adult male population, Gladstone's doctrine on Irish Home Rule, and the presenting of the first Home Rule Bill. But they cannot be said to be part of a "new departure" as they do not represent a complete rupture.

\section{BIBLIOGRAPHY}

\section{Sources primaires}

Hansard, Parliamentary Debates.

Barry O'Brien, R. (ed.), Home Rule, Speeches of John Redmond, M.P. (London, T. Fischer Unwin, 1910).

Gladstone, William E., Bulgarian Horrors and the Question of the East (London, J. Murray, 1876).

Guedalla, Philip, The Queen and Mr. Gladstone, 1800-1898 (London, Hodder \& Soughton, 1933).

The Irish Times

The Times

\section{Sources secondaires}

Bartlett, Thomas, "The Emergence of the Irish Catholic Nation, 1750-1850" in A. Jackson ed., The Oxford Handbook of Modern Irish History (Oxford, Oxford University Press, 2014) 
Bartlett, Thomas, “This Famous Island Set in a Virginian Sea: Ireland in the British Empire, 1690-1801", in Peter J. Marshall (ed.), The Oxford History of the British Empire, vol. 2: the Eighteenth Century (Oxford, Oxford University Press, 1998), pp. 253-75.

Beckett, J. C., "Gladstone, Queen Victoria, and the disestablishment of the Irish Church, 1868-9", Irish Historical Studies, 13:49 (1962), pp. 38-47.

Boyce, David George, "Federalism and the Irish Question," in A. Bosco (ed.), The Federal idea: The History of Federalism from the Enlightenment to 1945, vol. I (London, Lothian Foundation Press, 1991), pp. 119-38.

Buckland, P., Ulster Unionism II: Ulster Unionism and the Origins of Northern Ireland, 1886-1922 (Dublin, Gill \& Macmillan, 1973).

Colley, Linda, Britons: Forging the Nation, 1707-1837 (Yale, YUP, 2005 [1992]).

Cook, Chris \& John Stephenson, The Longman Handbook of Modern British History, 1714-1987 (London, Longman [1983], 1988).

Cook, Scott B., Imperial Affinities, Nineteenth-Century Analogies and Exchanges Between India and Ireland (New Delhi \& London, Oxford University Press, 1993).

Harbinson, J. F., The Ulster Unionist Party, Its Development and Organisation, 1882-1973 (Belfast, Blackstaff Press, 1977).

Howe, Stephen, Ireland and Empire: Colonial Legacies in Irish History and Culture (Oxford, Oxford University Press, 1996).

Isba, Anne, "Victoria”, Gladstone and Women (London, Hambledon Continuum, 2006), pp. 177-200.

Jackson, Alvin, “British Ireland: what if Home Rule had been enacted in 1912?", in Niall Ferguson (ed.), Virtual history: alternatives and counterfactuals (London, Pan, 2003), pp. 175-227.

Jackson, Daniel, Popular Opposition to Irish Home Rule in Edwardian Britain (Liverpool, Liverpool University Press, 2009).

Kenny, Kevin, Ireland and the British Empire (Oxford, Oxford University Press, 2004).

Le Jeune, Françoise, “About the so-called 'Colonial analogy' in the Home Rule debate: the case of the Canadian Dominion (1848-1886)”, in Philippe Brillet (ed.), La question du Home Rule (1870-1914) (Paris, Ellipses, 2018), pp. 191-232.

Lester, Alan, "Imperial Circuits and Networks. Geographies of the British Empire", History Compass (2003-5), pp. 1-18.

Murphy, James H., Abject Loyalty: Nationalism and Monarchy in Ireland during the Reign of Queen Victoria, (Washington, The Catholic University of America, 2001).

O'Day Alan and David G. Boyce, Defenders of the Union: A Survey of British and Irish Unionism Since 1801 (London, Routledge, 2001).

Pratt, Mary Louise, Imperial Eyes: Travel Writing and Transculturation (London and New York, Routledge,1992).

Prévost, Stéphanie, "Irish Home Rule and British Imperialism: A View through the Prism of the Bulgarian Question (1876-1886)", Cultures of the Commonwealth, $n^{\circ} 18$, The Local and the Global (2012), pp. 29-42

Shannon, Richard T., Gladstone and the Bulgarian Agitation 1876 (London, Thomas Nelson and Sons Ltd., 1963) 


\section{Sources Internet}

Rankin, Kieran J., “The search for 'statutory Ulster”, History Ireland, May-June 2009, https:// www.historyireland.com/revolutionary-period-1912-23/the-search-for-statutory-ulster/ [21 February 2019]

"Buckingham Palace Conference ends in failure", a page provided by RTE Ireland \& Boston College, "Century Ireland", https://www.rte.ie/centuryireland/index.php/articles/buckinghampalace-conference-ends-in-failure

\section{NOTES}

1. David George Boyce, "Federalism and the Irish Question," in A. Bosco (ed.), The Federal idea: The History of Federalism from the Enlightenment to 1945, vol. I (London: Lothian Foundation Press, 1991), 119.

2. There has been one attempt at counterfactual history: see A. Jackson, "British Ireland: what if Home Rule had been enacted in 1912?", in Niall Ferguson (ed.), Virtual history : alternatives and counterfactuals (London, Pan, 2003), pp. 175-227. Scholars have also identified a number of literary works or pamphlets as "home rule fiction": these futuristic tales are either nationalist or unionist and generally attempts to anticipate what the future of Ireland would be under a Home Rule Parliament (see for instance Edward James, "The Anglo-Irish Disagreement: Past Irish Futures", The Linen Hall Review 3, no. 4 (1986), 5-8 \& “1886: Past Views of Ireland's Future”, Foundation: The Review of Science Fiction 36 (Summer 1986), pp. 21-30 for the references and a description of some of these works).

3. John Redmond, House of Commons, 13 March 1894, in R. Barry O'Brien (ed.), Home Rule, Speeches of John Redmond, M.P. (London, T. Fischer Unwin, 1910), pp. 69-71.

4. It is beyond the scope of this introduction to give a wide range of sources on the subject. References reflecting the diversity of unionism and unionist responses to Home Rule include Alan O'Day \& David G. Boyce, Defenders of the Union: A Survey of British and Irish Unionism Since 1801 (London, Routledge, 2001) \& Daniel Jackson, Popular Opposition to Irish Home Rule in Edwardian Britain (Liverpool, Liverpool University Press, 2009).

5. Following the rejection of the first Home Rule Bill, a soldier and a head constable were killed in the constituency of West Belfast on 13 July 1886. This was followed by intermittent rioting throughout the summer of 1886. In total, 32 died and 337 amongst the police force were injured; 442 people were arrested, 32 pubs were destroyed and a number of houses were also damaged (J. F. Harbinson, The Ulster Unionist Party, Its Development and Organisation, 1882-1973 (Belfast, Blackstaff Press, 1977) p. 12). In 1893, protests were organised, including one in Belfast gathering 100,000 loyalists on 4 April 1893. Weapons were also imported (P. Buckland, Ulster Unionism II: Ulster Unionism and the Origins of Northern Ireland, 1886-1922 (Dublin, Gill \& Macmillan, 1973 pp. 17-8).

6. Adapted from Chris Cook \& John Stephenson, The Longman Handbook of Modern British History, 1714-1987 (London, Longman [1983], 1988), p.68.

7. Anne Isba, "Victoria", in Gladstone and Women (London, Hambledon Continuum, 2006), p. 177. See also Robert N. W. Blake, Gladstone, Disraeli, and Queen Victoria, Romanes centenary lectures (Oxford, Oxford University Press, 1993).

8. William E. Gladstone, Bulgarian Horrors and the Question of the East (London, J. Murray, 1876). This particular episode of British imperial history has actually been presented by some as the moment when Gladstone began to evolve towards more favourable positions regarding Home 
Rule : see Richard T. Shannon's Gladstone and the Bulgarian Agitation 1876 (London, Thomas Nelson and Sons Ltd., 1963) \& Stéphanie Prévost, "Irish Home Rule and British Imperialism: A View through the Prism of the Bulgarian Question (1876-1886)", Cultures of the Commonwealth, $n^{\circ} 18$, The Local and the Global (2012), pp. 29-42.

9. See James H., Murphy, Abject Loyalty: Nationalism and Monarchy in Ireland during the Reign of Queen Victoria, (Washington, The Catholic University of America, 2001), pp. 146-197 \& J. C. Beckett, "Gladstone, Queen Victoria, and the disestablishment of the Irish Church, 1868-9", Irish Historical Studies,13:49 (1962), pp. 38-47

10. Françoise Le Jeune, “About the so-called 'Colonial analogy' in the Home Rule debate: the case of the Canadian Dominion (1848-1886)", in Philippe Brillet (ed.), La question du Home Rule (1870-1914) (Paris, Ellipse, 2018), pp. 191-232.

11. Queen Victoria to W. E. Gladstone, 6 May \& 31 July 1886, quoted in Philip Guedalla, The Queen and Mr. Gladstone, 1800-1898 (London, Hodder \& Soughton, 1933), pp. 405 \& 423.

12. Kieran J. Rankin, “The search for 'statutory Ulster”, History Ireland, May-June 2009, https:// www.historyireland.com/revolutionary-period-1912-23/the-search-for-statutory-ulster/

13. Quoted in "Buckingham Palace Conference ends in failure", a page provided by RTE Ireland \& Boston College, "Century Ireland", https://www.rte.ie/centuryireland/index.php/articles/ buckingham-palace-conference-ends-in-failure, consulted on 21 February 2019.

14. Edward Carson, speech during the debates on the Government of Ireland Bill, Clause 1.(Establishment of Irish Parliament.), 1 January 1913, in Hansard, Debates of the House of Commons, vol. 46, c. 380 .

15. Lord John George Beresford, Arbishop of Armagh, Chancellor of Trinity College. Quoted by Thomas Bartlett, "The Emergence of the Irish Catholic Nation, 1750-1850" in A. Jackson ed., The Oxford Handbook of Modern Irish History (Oxford, Oxford University Press, 2014), p. 517.

16. L. Colley, Britons: Forging the Nation, 1707-1837 (Yale, YUP, 2005).

17. Alan Lester, "Imperial Circuits and Networks. Geographies of the British Empire", History Compass, 2003-5, pp. 1-18 \& Mary Louise Pratt, Imperial Eyes: Travel Writing and Transculturation (London and New York, Routledge, 1992), p. 8.

18. See for instance Scott B. Cook, Imperial Affinities, Nineteenth-Century Analogies and Exchanges Between India and Ireland (New Delhi \& London, Oxford University Press, 1993); Thomas Bartlett, "This Famous Island Set in a Virginian Sea: Ireland in the British Empire, 1690-1801", in Peter J. Marshall (ed.), The Oxford History of the British Empire, vol. 2: the Eighteenth Century (Oxford, Oxford University Press, 1998), pp. 253-75, \& Kevin Kenny, Ireland and the British Empire (Oxford, Oxford University Press, 2004).

19. Stephen Howe, Ireland and Empire: Colonial Legacies in Irish History and Culture (Oxford, Oxford University Press, 1996), pp. 36-7.

20. Dr Shashi Tharor (Indian MP and writer), "The Amristar massacre: a cold, callous display of colonial evil", The Irish Times, 21 January 2019, https://www.irishtimes.com/culture/heritage/ the-amritsar-massacre-a-cold-callous-display-of-colonial-evil-1.3744511, consulted on 21 February 2019.

21. Benjamin Disraeli, speech at the Crystal Palace, 24 June 1872 in The Times, "Mr. Disraeli at Sydenham", 25 June 1872.

22. Arthur Balfour, speech upon the third reading of the Government of Ireland Bill, 15 January 1913, in Hansard, Debates of the House of Commons, vol. 46, cc. 2014-2016. 


\section{AUTHORS}

\section{ANNE-CATHERINE DE BOUVIER}

Anne-Catherine de Bouvier, an alumna of the Ecole Normale Supérieure de Fontenay-St Cloud and agrégée d'anglais, is Associate Professor at the University of Caen, where she teaches Irish and British history, and translation. In 1998, she defended a PhD on Ireland's political elites 1800-1829. Her research focuses on politics and history of ideas in 19th century Ireland and Britain. She has just joined the editorial board of Etudes Irlandaises. She co-edited a special issue of the RFCB on the Great Irish Famine, 1845-1851, in 2014, with Christophe Gillissen; recently, she contributed to La Question du Home Rule en Irlande, 1870-1914 (C. Maignant, ed., Atlande, 2018).

Anne-Catherine de Bouvier, ancienne élève de l'Ecole Normale Supérieure de Fontenay-St Cloud et agrégée d'anglais, est Maître de Conférences à l'Université de Caen, où elle enseigne la civilisation irlandaise et britannique, ainsi que la traduction. En 1998, elle a soutenu une thèse sur les élites politiques en Irlande, 1801-1829. Ses recherches portent sur la politique et l'histoire des idées au XIX ${ }^{\mathrm{e}}$ siècle, en Irlande et en Grande-Bretagne. Elle vient de rejoindre le comité de direction d'Etudes Irlandaises. Elle a co-dirigé, avec Christophe Gillissen, un numéro spécial de la RFCB sur la Grande Famine en Irlande, 1845-1851, et a récemment contribué à La Question du Home Rule en Irlande, 1870-1914 (C. Maignant, dir., Atlande, 2018).

\section{PAULINE COLLOMBIER-LAKEMAN}

Pauline Collombier-Lakeman is a Maître de Conférences (lecturer) at the University of Strasbourg, where she teaches nineteenth- and twentieth-century history of the British Isles, and English language. After studying at the École Normale Supérieure de Fontenay St Cloud and passing the Agrégation, she was awarded her PhD from the Université Paris 3 - Sorbonne Nouvelle in 2007. Her research work has focussed on Irish parliamentary nationalism and on the relationship between Irish Home Rulers and the British Empire. She is the author of The Home Rule Question (1870-1914) published by Belin/CNED in 2018.

Pauline Collombier-Lakeman est Maître de Conférences à l'Université de Strasbourg, où, outre des cours de langue, elle enseigne l'histoire des Iles britanniques des XIX ${ }^{\mathrm{e}}$ et $\mathrm{XX}^{\mathrm{e}}$ siècles. Après ses études à l'Ecole Normale Supérieure de Fontenay-St Cloud et l'obtention de l'agrégation d'anglais, elle a soutenu une thèse à l'université Paris 3 - Sorbonne Nouvelle en 2007. Ses recherches portent sur le nationalisme parlementaire irlandais, ainsi que sur les relations entre les Home Rulers irlandais et l'empire britannique. Elle est l'auteur de The Home Rule Question (1870-1914) paru chez Belin/CNED en 2018. 